\title{
Path to Realize Principle of Law-based Taxation in China
}

\author{
Guilin Gao \\ School of Law in CUEB \\ Wuyi, Hebei
}

\author{
Yating Zhang* \\ CUEB \\ Shijazhuang, Hebei
}

\begin{abstract}
The principle of law-based taxation is one of the three basic principles of tax law, and it is the highest principle of them. The principle of law-based taxation is the basic principle to ensure smooth operation of taxation system in a country and the code that is strictly observed in different countries. The author believes that, provisions of article 56 of Constitution of China reflects the principle of law-based taxation, but the basically establishment of principle of law-based taxation has not yet been realized. It is an objective that China is currently striving for to realize the principle of law-based taxation in China, and also the purpose of the research. By comparing different western developed countries in their historical development and the provisions of the Constitution, the author analyzed the obstacles facing China, and concluded that, to realize the principle of lawbased taxation in China, it is necessary to improve the legislative authorization of tax and the legislation quality to clarify tax legislation; to collect taxes according to law and perfect the system and procedures to improve the implementation of taxation; to reduce restrictive conditions involved in the application for reconsideration and accelerate the pace of administrative law legislation to strengthen the judicial safeguard for tax.
\end{abstract}

Keywords-principle of Law-based taxation; clarify the tax legislations; enhancement of tax enforcement; strengthen judicial safeguard for tax

\section{DEFINITION AND EVOLUTION OF PRINCIPLE OF LAW-BASED TAXATION}

\section{A. Definition of Connotation of Principle of Law-based Taxation}

For the principle of law-based taxation, also known as statutory taxation principle, principle of taxation by law [1] and Principle of Taxation under the Law [2], scholars have not yet reached a unified understanding of this concept. The principle of law-based taxation refers that the rights and obligations of the subject of tax payment can only be provided by the laws, and the various components of the tax law must be and can only be clearly defined by law; the rights and obligations of the main body of tax collector and payer can only build on the legal provisions, and any entity shall not perform taxation or tax exemptions and reductions without legal basis [3]. The principle of law-based taxation refers to the basic principle of tax law with which the legislator determines the tax matters. That is, if there is no corresponding law as the basis, the government cannot levy taxes, and citizens have no obligation to pay taxes. The subject of taxation must and only levy taxes according to law; the subject of tax payment must and only pay taxes according to law [4]. In summary, although the scholars above have made different expressions, it is not difficult for us to find a common ground of these expressions. The principle of law-based taxation aims to regulate the legal relation between taxpayer and subject of taxation by laws, and it means that, taxation must be conducted based on legal basis and tax levying and paying must strictly follow the laws.

The connotation of principle of law-based taxation can be generalized as the legislation of taxation elements, the specification of taxation elements and the legality of procedures. The legislation of taxation elements requires that the taxation elements must and only be stipulated by the legislative body, that is, Parliament or NPC(National People's Congress), by laws; that is to say, the constituent elements of taxation can only be stipulated by laws in narrow sense. Specification of taxation elements refers that, the taxation elements and the taxation procedure not only satisfy the legal provisions in narrow sense, but also be specific and detailed to avoid ambiguity. This requires that the content, purpose and scope, etc. should be specified when providing the rights and obligations of taxpayer, to make sure that the taxpayers are able to predict their property burdens in advance to avoid unnecessary misunderstandings. Meanwhile, with specification of taxation elements, the withholding agent can better conduct taxation works, and the judicial organ can better investigate and solve the dispute. Taxation according to law, also known as legality of procedures, refers that the administrative body of taxation must strictly follow the legal provisions when conducting taxation, and they are not allowed to arbitrarily change the taxation procedure and elements. Based on the principle, without definite articles of laws as basis, the administrative body of taxation has no rights to levy, stop levying, reduce or eliminate taxes. Meanwhile, it is necessary to point out that, it is not only tax authority's function and power to collect taxes according to law, but also their responsibility to do this. Without legal provisions, the tax authority does not have the right to determine whether to levy, which taxes to levy, when to levy and how to levy by overstepping the law.

\section{B. Evolution of Principle of Law-Based Taxation in Western Developed Country}

The principle of law-based taxation first appeared in the United Kingdom. "Great Charter of Liberties" in 1215 provided that, the decisions on taxation can't be performed 
unless it is approved by the king and the parliament, and taxation is not possible without approval. Later, "Petition of Right" in 1627 also reflected the principle of "No promise, no tax levy". There is no written constitution in the UK, but there are a series of constitutional documents that provide the separation of tax legislative power. Because the principle of "supremacy of parliament" is implemented in UK, rather than the separation of powers, the tax legislative power is held by the Parliament in UK, and the administrative body does not have the intrinsic legislative power. It can be said that, the legislative power is actually held by the government in UK or held by the political parties. Therefore, in real politics, the tax legislative power is controlled by ruling parties in UK [5].

The principle of law-based taxation was originated from "Declaration of the Rights of Man and of the Citizen" in France. "Declaration of the Rights of Man and of the Citizen" asserted that, people are born with many rights, such as freedom, security, property, etc. and these rights should not be restricted or deprived by others, and these rights can only be restrained by formulating relevant laws and regulations. The political system has been reformed for several times in France, and the political system of France is built on Semi-Presidential Republic, and the president's rights are greatly improved. The separation of powers is just formal in France, without any substantive effect. Without surveillance or control of relevant powers, the taxation enforcement power is significantly having greater status than the tax legislative power and the tax judicial power.

The principle of law-based taxation was originated from American representative's reiteration of objection of "Stamp Act” in 1765 in USA, and corresponding opinions are formed, that is, when the tax is levied on the people, it must be approved by the people. If the people do not agree, they cannot levy taxes on the people. Later, the establishment of the Constitution in 1787 clearly reflects the principle of "no promise, no tax levy" and "no representation, no tax levy". The proposal of these acts and their implementations realizes the core status of the principle of law-based taxation in its tax legislation, and the fundamental status of the principle of lawbased taxation in its tax legislation is established. The principle of law-based taxation of USA is based on the deep-rooted concept of the separation of powers and their balances, and congress, president and the Supreme Judicial Court (SJC) have different degrees of legislative power. As for the laws and regulations on taxes, the tax legislative power, the tax judicial power and the taxation enforcement power are held by different departments. In practice, they are mutually constrained, without one authority holding the highest power. The legal system of taxation is developing towards standardized direction.

The principle of law-based taxation is originated from the pacifist constitution after World War II in Japan. In terms of tax legislation, Constitution provided that, the legislative power is mainly held by Diet of Japan. As part of law making, the tax legislation is also implemented by Diet of Japan, and with the authorization by laws, the administrative organization can also perform tax legislation. Japan adapts a regime based on parliamentarism, and the Parliament holds the legislative power of the state. Constitution provided that; only when the draft passed by both houses of Parliament can the tax enforcing authority execute the corresponding power. In Japan, the judicial power is held by the highest judicial organ and its subordinate general judicial organs, and there is no administrative judicial organ or special judicial organ, which means that, the investigation of tax-related legal cases are investigated by general judicial organs. Relatively, they are less professional and poorly targeted. However, the Japanese court has the power to inquire into the constitutionality of laws, which provides a strong backup to Japan's judicial organ.

\section{ANALYSIS OF OBSTACLES FOR CHINA TO IMPLEMENT PRINCIPLE OF LAW-BASED TAXATION}

Based on the first edition of The Constitutions of the World, translated and edited by editorial board of China People's Procuratorate Press in October 2012, the author generally sorted out the status of principle of law-based taxation abroad. First, basically there are tax provisions in every country, and there are even tax provisions in African countries. Second, there are mainly several expressions in tax provisions of different countries: first, the citizens' obligation to pay taxes are provided in the chapter of fundamental rights and duties; second, it is provided in the special chapters of finance and tax; third it is provided in the chapters and sections of tax, fourth, it is provided in the setting of state institution. Third, there are no detailed regulations on the decentralization of authority between the central and local governments in most of countries, and the detailed provisions appear in only a few countries. Finally, in general, the principle of law-based taxation is relatively prominent in some of countries. For example, the statutory provision of tax is clearly specified in Brunei, according to article 56, "The taxes at the national and local level are stipulated by laws [6]", and the second clause of Definitions and Interpretations also provided detailed explanations of it to avoid ambiguity. There are many sections and clauses in Indian Constitution explaining the taxations, including the definition of the law, the rights of national institutions and the rights of local government.

By comparing different western developed countries in their evolutions of principle of law-based taxation and reviewing the book of "The Constitutions of the World", I come to realize that, there are a lot of obstacles for China to gradually implement the principle of law-based taxation. The main reason is that, it has not been a long time since the principle of law-based taxation was introduced to China. Although Chinese scholars and governments have increased their efforts in learning and research, there are still some shortcomings to overcome. To better implement the principle of law-based taxation, it is necessary to analyze the obstacles from three aspects, that is, legislation, law enforcement and judiciary.

\section{A. Chaotic System of Tax Legislation}

Legislative Law is one of most important links of legal construction and it is the precondition of law enforcement, judiciary and law observation. Tax legislation is one of most important links of state's regulation of tax revenue, and it is an irreplaceable measure. Currently, there are many obstacles facing China's tax legislation. 
1) There are defects in the mode of legislative authorization of tax

So far, there are only four laws in China' s tax law system, that is: "Law on Personal Income Tax", "Law of Enterprise Income Tax", "Law on the Administration of Tax Collection" and "Law on Vehicles \& Ships Taxes". However, there are a lot of normative documents in addition to the laws, for example, about 30 administrative laws and regulations, 50 administrative regulations on taxes and more than 5000 tax announcements. In practice, it is always these ineffective tax announcements which exert the main function. The reasons for this is that, a lot of administrative organizations are authorized with the powers twice before and after the beginnings of reform and opening up, so a lot of administrative laws and regulations on taxes were promulgated. The problems of China's delegated legislation are: too many legislative delegations, blank authorization and delegation. The great number and broad range of legislative delegation is the major problem. The blank authorization refers that, when the legislative subject authorize other organizations with the legislative powers, it doesn't clearly define the scope of delegation, or propose clear requirement on the content, purpose, scope and duration, etc. of authorization. Currently, the tax legislation is dominated by administrative organs in China, and the State Council almost holds the legislative powers on taxes of all kinds through the legislative authorization of tax. Due to the lack of clear provisions on the scope and duration of delegation and the incomplete surveillance by the legislative body, the phenomenon of delegation is quite common.

\section{2) Poor quality of tax legislation}

The tax legislation quality not only directly affects the immediate interests of taxpayer, but also matters the process of China's taxation development and tax governance in accordance with the law. Currently, there are several problems in tax legislation quality: first, there is no uniformity and coordination provided by the fundamental laws of tax. China's current legal system of taxation is: led by Constitution, with considerable amount of laws on tax collection, administrative laws and regulations, tax convention as the main body, supplemented by some rules and regulations on tax, policy document etc., the system of tax law is formed [7]. Second, the tax legislation capability and the professionalism are not sufficient. As the legislative body, NPC is comprised of famous scholars, civil servant and heads of enterprises and public institutions, but few of them are representatives of the People's Congress in Grass Roots or judicial and other legal professionals.

\section{B. Poor Tax Enforcement Conditions}

The execution of tax laws is an important link of implementing the principle of law-based taxation. Poor execution will lead to serious consequences, and even though the solid content follows the principle of law-based taxation, it can't make up for the loopholes in the execution procedure.

\section{1) Taxation violates the legal provisions}

First, because the local government has the right to formulate the tax regulations, the local protection may be easily formed, and it would introduce more favorable policies to compete with other regions and the gaps between different regions may be deteriorated. Different local governments would adopt various means to formulate rules or regulations favorable to it, to evade the legal purpose. Second, it lacks supervisory mechanism and remedy procedure, which may easily lead to Performing Organization's noncompliance with the laws. Even though the Performing Organization does not act by law, the taxpayer does not have any effective countermeasures and the Performing Organization will not be subject to any punishment. Finally, the good and bad are intermingled among the officers, and it would lead to poor enforcement. Especially, some senior law enforcement officers would easily violate laws, because they don't actively learn new knowledge, or adapt themselves to the current situation of tax collection and management. Besides, some law enforcement officers have poor sense or awareness of responsibility, which is one of reasons which explain poor taxation enforcement.

\section{2) Procedural provisions are violated during taxation}

As for taxation, there are not only provisions of substantial law, but also procedural provisions. Meanwhile, legality of procedures is one of three elements involved in the principle of law-based taxation, and it is a provision that we shall observe. If the punishment is made by violating the Taxation Procedures, then it is an illegal law enforcement act. Because some lawexecutors just want to avoid troublesome procedures and show no respect for enforcement procedure, and they don't perform duties according to legal provisions, they are not cooperate in the event of tax affairs dispute, and a lot of problems occur in the process of taxation. As time passes, the taxpayer has reduced degree of recognition for the taxes, making it difficult to accomplish the law enforcement works. Besides, in recent years, as the taxpayer's awareness of asserting rights and the concept of rule of law is enhanced day by day, the lawsuits caused by the imperfect enforcement of procedures display a growing trend. Currently, there are considerable amounts of laws related to taxes, while there is a few of them are laws and regulations on procedures. The tax collection procedure is only mentioned in "Tax Administration Law". However, the provisions aren't specific, so there is no common measure for the law-enforcing works.

\section{Lack of Support for Tax Judiciary}

The tax judiciary is the last measure for taxpayer to seek for relief, so we need to make every effort to ensure the legitimate interest of taxpayer. However, the tax judiciary lacks support in real life, which is reflected at the following aspects:

1) The reconsideration mechanism for tax affairs is not reasonable.

Article 83 of "Tax Administration Law" provided that, if the taxpayer and the tax authority are in dispute over the tax issues, the taxpayer shall pay the tax in full amount as requested by the withholding agent, or provide guarantees; otherwise, the taxpayer does not have the right to apply for administrative reconsideration. If there are problems with the tax authority identified in the process of administrative reconsideration, the taxpayer will be refunded the overpaid taxes. As for such provisions, the taxpayers are placed at a passive position that violates the taxation regulations, and this 
attitude of "emphasis on institution, and neglecting the individuals.”

2) Insufficient supplies to China's tax judiciary First, administrative laws and regulations need to be improved

"Administrative Procedure Law" is one of the basic legal documents promulgated by the state, while some of supportive laws and regulations haven't been promulgated yet. Even the laws like "Administrative Reconsideration Law', "Law on Administrative Penalty" and "National Compensation Law" etc. are promulgated, the imperfect legal systems difficult to overcome. Therefore, the functions of "Administrative Procedure Law” can't be fully exercised. Second, when investigating such kind of cases, the power that the court can exercise is too narrow, and the administrative act can't be fully monitored. "Administrative Procedure Law" proposed some requirements on the cases that the court has the power to accept and investigate. However, because of these requirements, the cases that the court investigates can't cover all the civil dispute and some of cases can't be solved by the court in a fair and justified way.

\section{PATH FOR CHINA TO REALIZE THE PRINCIPLE OF LAW-BASED TAXATION}

In the Third Plenary Session of the 18th Central Committee of the CPC, it was required to practice the principle of lawbased taxation, and it is a need to conform to the times. General Secretary Xi Jinping proposed, in the report of the 19th National Congress of the Communist Party of China, that the principal contradiction in Chinese society is that between the ever-growing needs of the people for a better life and unbalanced and inadequate development. It is one of important links to solve tax problems by practicing the principle of lawbased taxation, while the tax problem is one problem that leads to the principal contradiction. Therefore, the implementation of the principal contradiction in Chinese society helps solve the principal contradiction in Chinese society. To realize the principle of law-based taxation in China the author proposed that the works could be done from the following points:

\section{A. Clarify the Tax Legislations}

The question of fundamental importance in realizing the principle of law-based taxation in China is to clarify the tax legislation and set right the relation between the legislative body and the administrative body. In other words, it is necessary to implement "Legislative Law" and "Law on the Administration of Tax Collection" and so on, and the National People's Congress and It's Standing Committee should recover the tax legislative power; to properly distribute the tax legislative power at the national and local level. In details,

\section{1) Enhance the legislative authorization of tax.}

First, NPC should abolish the delegated legislation of 1985, and clear the existing administrative laws and regulations on taxes step-by-step, level-by-level, and layer-by-layer and promote them to the level of laws. At the same time, considering the stability and continuity of legal provisions, the effectiveness of current regulations should be recognized, and the State Council is allowed to change, interpret and introduce detailed rules and regulations. Second, it is necessary to sort out the relations of laws on tax collection to tax administrative laws and regulations etc. and build a scientific and coordinated system of tax laws and regulations. The principle of law-based taxation does not mean that the delegated legislation will be forbidden in the future, but these delegations should be made under the Framework of the Rule of Law and they should aim at specific items with definite scope and requirement. "Blank authorization" which is vague and broad isn't suggested; the principle of law-based taxation does not mean that it will absolutely repel other sources of law such as tax administrative laws and regulations. The State Council can still formulate tax administrative laws and regulations based on delegation or for the purpose of implementing laws. The competent department of finance and taxation can also introduce specific interpretations and detailed rules and regulations based on the laws. Different sources can exert their functions within their range of power, and they can work with each other to form a legal system of tax with multiple layers.

\section{2) To enhance the legislation quality}

The key to enhance the legislation quality is to improve legislation capability of NPC [1]. The right of the state to levy tax and the duty of taxpayer to pay taxes are originated from the provisions of the laws in narrow sense, that is, the laws formulated by NPC and its Standing Committee. The taxation would reduce taxpayer's property and constrain their right to freely dispose their own property, so its legitimacy can't be guaranteed without the consent of the people. It helps improve the democratization of legislation by enlarging the participation of the people so as to ensure the fairness of taxation. There are problems such as disorder and ambiguity in the laws on tax collection; to solve this problem, it is necessary to enhance legislative level and detail the content of laws on tax collection. In the process of legislation, it is suggested that the dependence on the tax laws drafted by competent departments in finance and taxes should be gradually reduced to better embody the will of the people and the dominant status of legislative body in tax legislation. At the same time, it is suggested that the procedure and mechanism of legislation of NPC should be further perfected to strengthen the power of NPC and its Standing Committee as a legislative body that represents the will of the people [8].

\section{B. Enhancement of Tax Enforcement}

\section{1) To collect taxes according to law}

To practice the principle of law-based taxation, we not only need to clarify tax legislation, but also need to make sure that there are laws for people to follow. It is suggested that the withholding agent collect taxes according to law. On the one hand, the abuse of power to levy taxes committed by local government should be forbidden. As mentioned above, the local governments would adopt various means to formulate rules or regulations favorable to it by various means to evade the original purpose of laws and violate the statutory procedures, and this would greatly harm the rights of taxpayers In practice, we should strictly implement the principle of lawbased taxation, and make sure that the taxes are collected according to laws, and the secret deal between withholding agent and taxpayer and the unfairness in juridical practice should be forbidden. On the other hand, it is necessary to enhance the quality of law enforcement officer and strengthen their sense of responsibility, and make sure that the law 
enforcement officer recognizes the importance and significance of tax collection by law.

\section{2) Perfect the support for procedural system}

Legally prescribed procedure is one of important content of legally prescribed taxation. The legally prescribed procedure can't be implemented if the entity is legally prescribed while the procedure is not legally prescribed. Therefore, to make sure that the entity is legally prescribed, that is, the elements are legally prescribed and specific, it is necessary to make sure that the procedure is legally prescribed, and there are strict provisions on the procedures such as taxpaying and imposing. To strengthen the effort in making government affairs public and place the law enforcement power under the "sunlight", the tax authority needs to vigorously promote the governmental information disclosure system, improve the taxation transparency, disclose taxation procedure, taxation results, perfect the disclosing procedure, broaden the disclosed content and standardize the forms of disclosure. It is necessary to constantly perfect tax law announcement, taxation review and approval, notice of outstanding tax, decisions on tax deduction and tax reimbursement, punishment and taxpayer's credit ranking and other disclosure system. Except for the state secret and the business secrets and personal privacy that should be protected according to law, for all kinds of matters and information that need to be understood, observed and implemented by taxpayers, the tax authority shall disclose to the public through bulletin board in tax service center, tax website and media and so on.

\section{Strengthen Judicial Safeguard for Tax}

1) Reduce restrictive conditions on applying for reconsideration

It is suggested that the regulations are reduced, and some unreasonable preconditions are removed. No matter whether the subject of right has paid the taxes when he applies for reconsideration or not, whether the content to be reconsidered targets at the specific administrative act, sufficient room should be provided for the reconsideration. This is result obtained by strengthening law enforcement and supervision and separating the power of taxation from the right of relief. Therefore, the tax collection authority would not make interference to the acts of legal remedy. Under the existing legal framework, the taxation behaviors are positive interaction between the taxpayer and the government. The latter collects taxes according to regulations, and the former can also seek relief in accordance with the law once it considers that its own rights and interests are damaged during the taxation process.

2) Accelerate the pace of administrative law legislation

At present, although the tax administrative law is subject to judicial review, the legislation of the administrative organ is not subject to review. This has caused a gap between the judicial basis and the actual rationality and has also led to deviations in the guidance of specific regulations on specific administrative actions. Therefore, it is necessary to strengthen the restriction and supervision of administrative power, incorporate the legislation of the state administrative organs into judicial review, to further protect the rights and interests of taxpayers by improving the regulations. In order to improve the uniformity and standardization of the laws on which the judicial decision is based, it is necessary to strengthen the supervision of the court process. Once the normative document is found to be in violation of the law by the court, it should be declared abolished when the judgment is made.

\section{REFERENCES}

[1] Jin Zihong. Lease Tax Law, the translation of which is "The Principles of Japanese Tax Law", translated by Liu Duoda, China Finance and Economics Publishing House, 1989, p. 47

[2] Chen Qingxiu. Taxation Legalism, Contemporary Public Law Theory, Ludan Publishing Company, 1993. Page 589. (In Chinese).

[3] Zhang Shouwen. Statutory taxation principle. On the Statutory Taxation Principle [J]. Research on Laws, 1996, 06:57. (In Chinese).

[4] Liu Jianwen. Significance and Path to Practicing the principle of lawbased taxation [J]. NPC of PRC, 2017(19):35-41. (In Chinese).

[5] Liu Jianwen: Basic Issues in China's Tax Legislation [M], Beijing: China Taxation Press, 2006: 22. (In Chinese).

[6] Compilation Committee of the Constitutions of the World: Compilation of the Constitutions of the World (Asian Volume), Beijing: China Procuratorate, October 2012, 1st edition, p. 644.

[7] Zhang Yijun: Research on the legislation problems in "Fundamental Laws of Tax" [J], Tax and Economic Research, 2015(5):35-43. (In Chinese).

[8] Zhu Daqi. On spiritual essence and its implementation of principle of law-based taxation [J]. International tax, 2014, 05, 13. (In Chinese). 